\title{
KERAGAAN PERTUMBUHAN DAN VARIASI GENETIK ABALON Haliotis squamata Reeve (1846) HASIL SELEKSI F-1
}

\author{
Gusti Ngurah Permana", Ibnu Rusdi, Fitri Husnul Khotimah, Sari Budi Moria Sembiring, dan Haryanti \\ Balai Besar Penelitian dan Pengembangan Budidaya Laut
}

(Naskah diterima: 29 Januari 2015; Revisi final: 30 Oktober 2015; Disetujui publikasi: 9 November 2015)

\begin{abstract}
ABSTRAK
Produksi benih abalon Haliotis squamata skala massal di hatcheri telah berhasil dilakukan di Balai Besar Penelitian dan Pengembangan Budidaya Laut Gondol, Bali. Permasalahan utama dalam budidaya abalon adalah pertumbuhan yang lambat. Keadaan tersebut diduga karena pengaruh faktor genetik dan lingkungan. Penelitian ini bertujuan mengetahui keragaan pertumbuhan dan variasi genetik abalon tumbuh cepat hasil seleksi individu. Hasil penelitian ini diketahui bahwa pembentukan populasi F-1 mempunyai pertumbuhan yang lebih baik dengan F-1 kontrol. Peningkatan bobot yang dicapai 22,15 g atau 17,93\% lebih baik dibandingkan F-1 kontrol. Keragaman genetik F-1 terseleksi yang ditunjukkan dari nilai heterozigositas adalah (Ho. 0,023) terjadi penurunan 21,7\% jika dibandingkan F-0. Hal ini dapat terjadi karena hilangnya beberapa allele dalam proses seleksi. Terdapat hubungan antara jumlah heterozigot pada lokus tertentu dengan pertumbuhan abalon. Hasil ini diharapkan dapat mendukung upaya meningkatkan produksi benih yang mempunyai performa fenotipe dan genotipe unggul sehingga dapat mendukung kegiatan budidaya abalon yang berkelanjutan.
\end{abstract}

KATA KUNCI: variasi genetik, seleksi, tumbuh cepat, abalon

ABSTRACT: $\quad$ Performance of growth and genetic variation abalon Haliotis squamata Reeve (1846) of F-1 selected. By: Gusti Ngurah Permana, Ibnu Rusdi, Fitri Husnul Khotimah, Sari Budi Moria Sembiring, and Haryanti

Production of abalone (H. squamata) in hatcheries has been developed at the Institute Marine Research and Development Gondol, Bali. The main problem in abalone farming is slow growth during juvenile stage. This is suggested due to genetic and environmental factors. The aims of this study was to evaluate genetic variations of fast growing individual selected of abalone with individual selection. The result showed that information of F-1 population have better growth with the F-1 control. Increasing body weight of abalon F-1 of $22.15 \mathrm{~g}$ (17.93\%). The genetic variaton indicated from heterozygosity value of selected F-1 (Ho. 0.023) and F-0 (Ho. 0.019), reduction of genetic variation of 21.7\%. Its may possible due to loss of some alleles during the selection process. There is a relationship between the number of loci heterozigot in particular with growth of abalone. These results are expected to increase the production of seeds that have genetic and phenotypic with better performance to support sustainable abalone farming.

KEYWORDS: genetic variation, selection, fast growth, abalone

\section{PENDAHULUAN}

Abalon H. squamata bersifat plankton feeder dan herbivora termasuk organisme low tropic level yakni pada fase larva memakan diatom bentik dan dewasa memakan rumput laut/makroalga. Dengan demikian dapat dikatakan bahwa biaya produksinya relatif

\# Korespondensi: Balai Besar Penelitian dan Pengembangan Budidaya Laut. Jl. Br. Gondol, Kec. Gerokgak Kab. Buleleng, Kotak Pos 140, Singaraja, Bali 81101, Indonesia.

Tel.: + (0362) 92272

E-mail: info.gondol@gmail.com murah. Hal inilah yang menarik dari komoditas abalon sehingga perlu kajian dalam teknologi budidayanya.

Produksi benih abalon skala massal telah berhasil di Balai Besar Penelitian dan Pengembangan Budidaya Laut (BBPPBL) Gondol, Bali dengan perolehan sintasan benih umur dua bulan berkisar 6,3\%-18,4\% di hatcheri Gondol, Bali (Rusdi et al., 2009). Namun demikian, permasalahan utama adalah pertumbuhan yang lambat. Keadaan tersebut sangat tergantung pada faktor genetik dan lingkungan. Faktor genetik selain memengaruhi kualitas juga akan memengaruhi produktivitasnya. Salah satu metode rekayasa genetik 
yang dapat dilakukan adalah seleksi individu menggunakan parameter bobot badan.

Sampai saat ini kajian dan informasi keragaman genotipik pada abalon masih terbatas. Untuk itu, perlu dilakukan evaluasi lanjutan terkait kajian genotipik. Di samping keragaman genetik, informasi penting lainnya yang diperlukan adalah heritabilitas karakter komponen hasil dan korelasi antar karakter. Informasi korelasi antar karakter sangat diperlukan untuk memudahkan proses seleksi. Nilai heritabilitas tinggi menunjukkan faktor genetik lebih berperan dalam mengendalikan suatu sifat dibandingkan faktor lingkungan (Poehlman, 1979).

Teknik biokimia dan molekuler telah banyak dipergunakan untuk mengukur keragaman atau kualitas genetik suatu spesies. Allozyme elektroforesis dengan menguji pergerakan molekul protein di bawah pengaruh medan listrik sebagai salah satu metode yang paling umum dipergunakan (Permana et al., 2003). Selain itu, marker molekuler DNA dapat digunakan sebagai metode yang lebih sensitif dengan akurasi data tinggi. Tujuan dari penelitian ini adalah mengetahui keragaan pertumbuhan dan variasi genetik abalon, $H$. squamata hasil seleksi tumbuh cepat.

\section{BAHAN DAN METODE}

Penelitian dilakukan di Hatcheri Multi Spesies BBPPBL Gondol, Bali. Kegiatan ini dimulai dari pemilihan induk yang siap memijah masing-masing 50 ekor jantan dan 50 ekor betina. Induk abalon H.squamata mempunyai kisaran 6,5-7,0 cm. Pemeliharaan larva pada bak beton yang berukuran 4,2 m x 2,3 m x 1,2 m sebanyak dua bak. Pada bak ditempatkan substrat penempelan larva yang telah ditumbuhi bentik diatom sebagai pakan larva dari bahan plastik fiber bergelombang berukuran $58 \mathrm{~cm} \mathrm{x}$ $60 \mathrm{~cm}$. Veliger yang ditebar sebanyak 150.000 ekor merupakan keturunan F-1 dari hasil pembenihan. Kultur diatom pada substrat pemeliharaan/rearing plate dilakukan dua minggu sebelum penebaran. Sumber air yang digunakan adalah air laut yang berasal dari perairan Teluk Gondol yang telah melewati proses filtrasi filter pasir dan proses ultraviolet (UV). Pemberian pakan makroalga di mulai pada pemeliharaan hari ke-60. Makroalga yang diberikan adalah jenis Gracilaria verrucosa dan Ulva sp. dengan dosis adlibitum. Pendederan dan pembesaran benih dilakukan pada bak semen volume ukuran $2,3 \mathrm{~m}^{3}(240 \mathrm{~cm}$ x $110 \mathrm{~cm}$ x 90 $\mathrm{cm})$. Benih ditempatkan pada keranjang ukuran $35 \mathrm{~cm}$ x $25 \mathrm{~cm}$ x $8 \mathrm{~cm}$. Padat tebar yang digunakan $125-150$ ekor/keranjang.

Metode seleksi individu mengacu pada standar prosedur operasional pemuliaan abalon yang dibuat oleh Balai Besar Penelitian dan Pengembangan Budidaya Laut Gondol Tahun 2010. Setelah umur empat bulan dilakukan cut off $50 \%$. Jika ukuran per individu keragamannya kecil (ukuran rata), maka langsung dilakukan pemotongan sebanyak $50 \%$ dari populasi. Jika ukuran per individu keragamannya besar, maka dilakukan pengukuran (panjang dan bobot) sebanyak 100 ekor (5\%-10\% dari populasi). Selanjutnya dihitung rata-rata dan sebarannya, diambil sebanyak $50 \%$ dari jumlah populasi. Pada umur delapan bulan dilakukan seleksi $1 \%-5 \%$ dengan cara dilakukan pengukuran (panjang dan bobot) sebanyak 100 ekor (5\%-10\% dari populasi). Rata-rata dan sebarannya dihitung dan dan diambil $1 \%-5 \%$ populasi terbaik.

Parameter yang diamati adalah bobot, panjang cangkang, dan pengukuran kualitas air dilakukan sebagai data penunjang penelitian. Analisis genetik sampel F-0 dan F-1 menggunakan allozyme elektroforesis dengan menguji tiga belas enzim yaitu (Alcohol dehydrogenase (1.1.1.1), f-Glycerolphosphate dehydrogenase (1.1.1.8), Lactate dehydrogenase (1.1.1.27), Malate dehydrogenase (1.1.1.37), Isocitrate dehydrogenase (1.1.1.42), Phosphoglucomutase (2.7.5.1), 6-Phosphogluconate dehydrogenase (1.1.1.44), Glucose phosphate isomerase (5.3.1.9), Malic enzyme (1.1.1.40), Esterase (3.1.1.3), Peptidase le ugly gly, Carbonic anyhydrose, dan Sarcoplasmic protein. Prosedur pelaksanaan mengikuti metode yang dikembangkan oleh Sugama \& Prijono (1998). Analisis Mt-DNA menggunakan PCR : dengan menggunakan primer forward : FPHDiv (TGATCYGGMYTAGTCGGAACYGC) dan primer reverse: BPHDiv (GATGTRTTRAARTTACGGTCRGT) yang merupakan modifikasi dari primer mtCOI Forward (TGATCCGGCTTAGTCGGAACTGC) dan primer reverse (GATGTGTTGAAATTACGGTCGGT) dari primer spesifik untuk H. rufescens (Metz et al., 1998). Elektroforesis menggunakan gel agarose $2 \%$ dalam $0,5 \mathrm{x}$ buffer SB.

Analisis data yaitu frekuensi alel, jumlah alel per lokus, heterozigositas rata-rata dan proporsi lokus polimorfik, serta keragaman haplotipe. Data yang diperoleh dari hasil intepretasi pita yang muncul (teramplifikasi) selanjutnya dipergunakan untuk menghitung beberapa parameter keragaman genetik populasi menurut Lynch \& Miligan (1994) dan Allendorf \& Utter (1979).

\section{HASIL DAN BAHASAN}

\section{Seleksi Pertumbuhan}

Seleksi pertumbuhan merupakan program perbaikan genetik yang dilakukan dengan menyeleksi individu berdasarkan keunggulan pertumbuhannya. 
Kemajuan seleksi dapat diartikan sebagai nilai kemajuan genetik yang secara teoritis merupakan besarnya kenaikan hasil yang akan diperoleh sebagai akibat dari dilakukannya kegiatan seleksi terhadap suatu populasi. Untuk mengetahui seberapa besar kemajuan seleksi yang diperoleh, diperlukan pengetahuan tentang populasi dan keragamannya. Kegiatan produksi benih untuk pembentukan populasi F-1 terlihat pada Gambar 1.

Menurut Stickney (2000), pertumbuhan abalon sangat lambat dan berbeda antara satu spesies dengan lainnya. Fase metamorfose hingga terbentuknya lubang pernapasan membutuhkan 60-90 hari, pertumbuhannya hanya berkisar 1,0-2,5 $\mathrm{mm}$ per bulan dengan panjang cangkang 2,0-2,5 mm (Rusdi et al., 2009). Pertumbuhan panjang dan lebar cangkang abalon hasil seleksi lebih cepat dibandingkan hasil penelitian (Rusdi et al., 2009) yaitu pada pemeliharaan 75 hari mencapai panjang cangkang 0,98 $\pm 0,13 \mathrm{~cm}$; lebar cangkang 6,1 $\pm 1,2$; dan bobot badang $0,2 \pm 0,1 \mathrm{~g}$; dibandingkan dengan penelitian. Yuwana yang dipelihara sampai umur empat bulan, sejumlah 40.000 ekor diambil rataan 50\% terbaik diperoleh hasil seleksi sebanyak 20.000 ekor.

Tahap seleksi jantan mempunyai panjang cangkang $36,8 \pm 0,27 \mathrm{~mm}$ dan betina $36,8 \pm 0,25 \mathrm{~mm}$; lebar cangkang abalon jantan $22,0 \pm 0,17 \mathrm{~mm}$ dan betina 21,9 $\pm 0,14 \mathrm{~mm}$, sedangkan bobot total (o' 6,9 \pm
$1,82 \mathrm{~g}$ ) dan (o 6,8 $\pm 1,2 \mathrm{~g})$. Setelah umur 12 bulan individu betina mempunyai ukuran yang lebih besar daripada jantan. Data hasil seleksi tumbuh cepat terlihat pada Tabel 1.

Nilai heritabilitas abalon hasil seleksi jantan dan betina terlihat pada Tabel 1. Nilai rata-rata heritabilitas dari total populasi terpilih dengan jumlah 1.000 ekor adalah untuk panjang cangkang $(0,77)$, lebar cangkang $(0,74)$, dan bobot badan $(0,87)$. Semakin besar nilai heritabilitas maka akan semakin besar nilai respons seleksi yang diinginkan. Heritabilitas menunjukkan besarnya pengaruh variasi aditif yang dihasilkan. Lebih lanjut menurut Carsono et al. (2004), nilai duga heritabilitas yang tinggi menunjukkan bahwa faktor genetik lebih berperan dari faktor lingkungan, sedangkan nilai duga heritabilitas yang rendah mempunyai nilai sebaliknya.

Nilai respons seleksi (response of selection) pada F1 , terlihat adanya peningkatan panjang cangkang 2,68 $\mathrm{cm}(49 \%)$, lebar cangkang 1,65 (50\%), dan bobot badan yang dibandingkan kontrol adalah sebesar 22,15 g $(85,0 \%)$. Berdasarkan seleksi yang dilakukan menunjukkan nilai respons seleksi calon induk abalon Bali yang cukup besar yaitu 3,97 g atau 17,93\%. Menurut Gustiano et al. (2008), nilai respons seleksi ikan nila (Oreochromis niloticus) dengan seleksi famili adalah 17,20\% dan menurut Ponzoni et al. (2005),
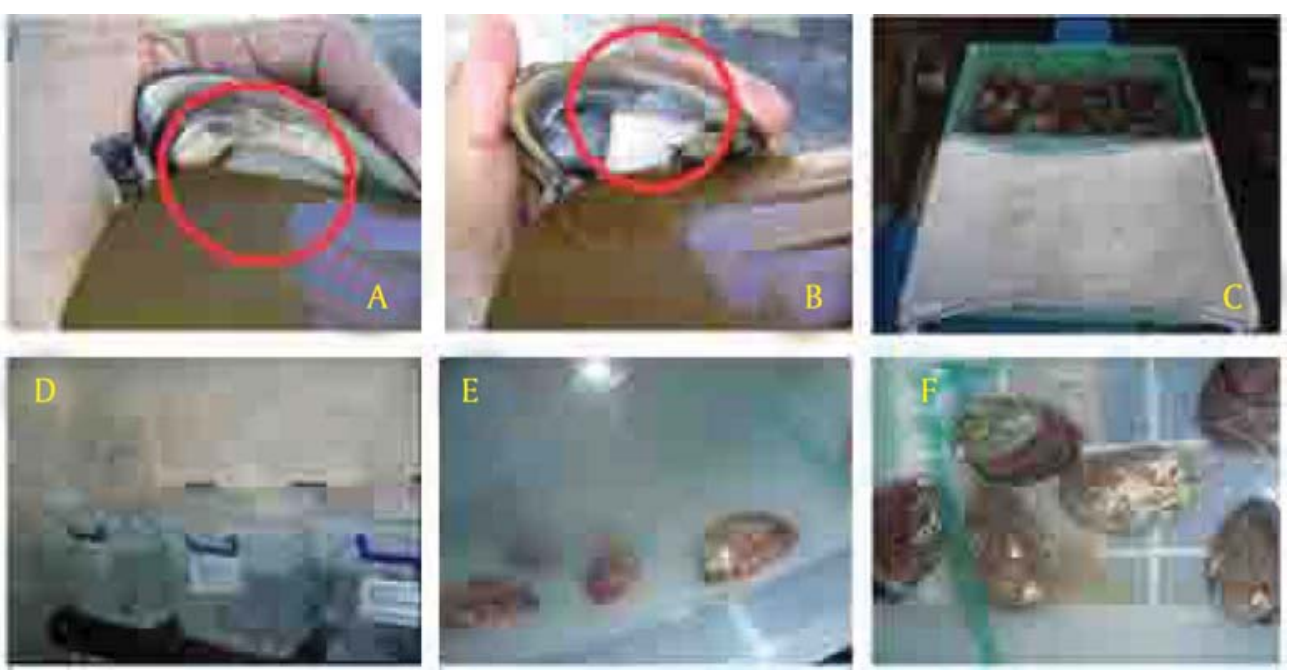

Keterangan (Description):

A: Gonad induk jantan (warna krem) (Adult male gonad (beige color))

B: Gonad induk betina (warna hijau kehitaman) (Adult female gonad (blackish green))

C: Proses pengeringan induk (Dry up broodstock)

D: Pemijahan dengan manipulasi oksigen murni (Manipulation spawning with pure oxygen)

E: Sperma yang keluar dari induk jantan (air berwarna putih susu) (Sperm of the male broodstock (milky water))

F: Telur yang keluar dari induk betina (telur berwarna kehijauan) (Eggs of the female parent (greenish eggs))

Gambar 1. Seleksi induk jantan-betina dan pemijahan abalon (H. squamata)

Figure 1. $\quad$ Mating female-male and spawning activity of abalone (H. squamata) 
Tabel 1. Data seleksi pertumbuhan abalon (H. squamata) umur 12 bulan (Pc $=$ panjang cangkang, $\mathrm{Lc}=$ lebar cangkang, Bt $=$ bobot total)

Table 1. Measurements data on growth selection of abalone (H. squamata) reared in 12 month (Pc = shell length, Lc $=$ shell width, $B t=$ total weight)

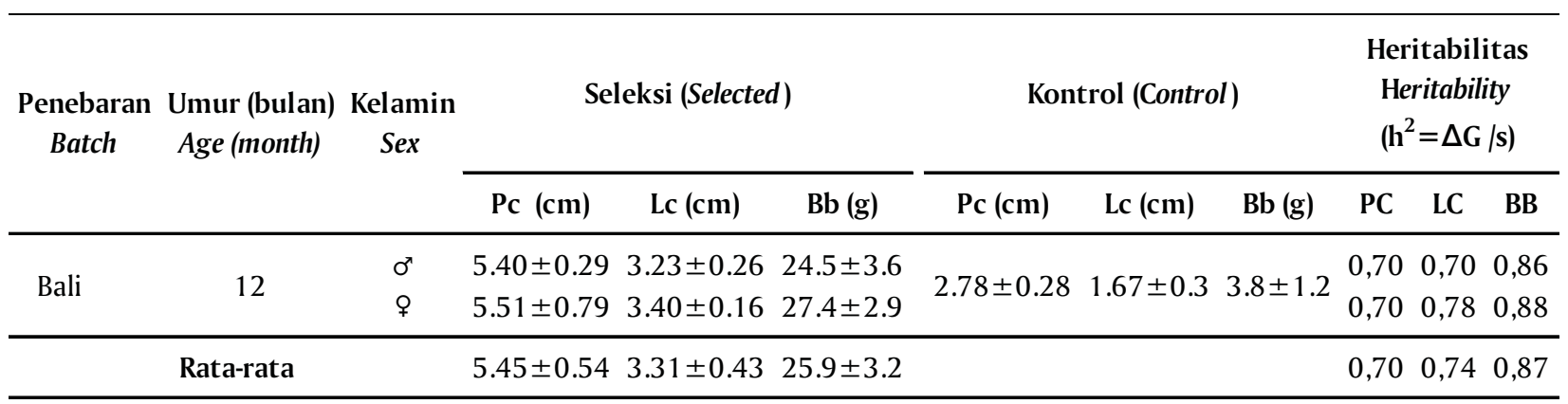

Keterangan (Description): Pc: panjang cangkang (shell length), Lc: lebar cangkang (shell width), Bb: bobot badan (total weight), $\Delta \mathrm{G}$ : kemajuan genetik (delta genetic)

A

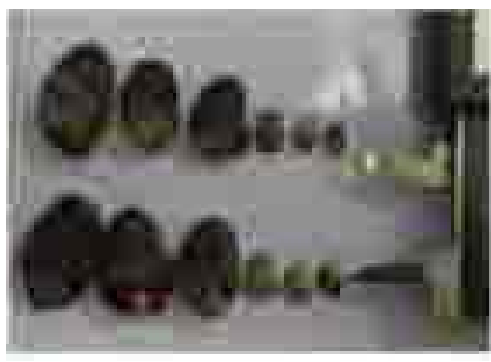

B

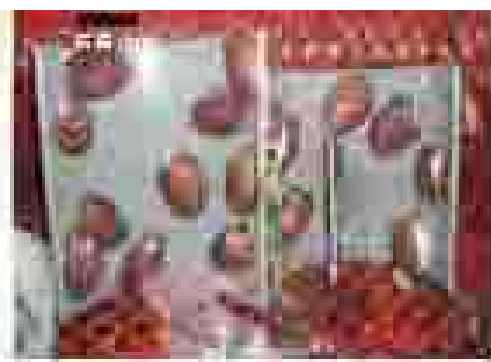

C

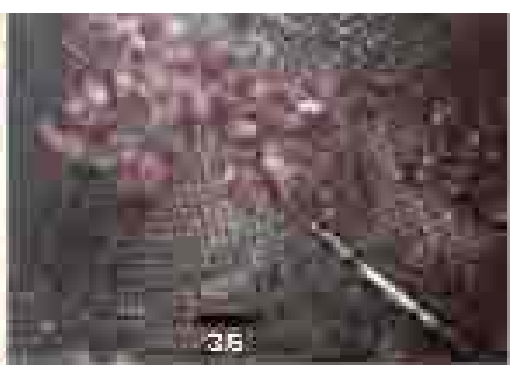

Gambar 2. Variabilitas morfologi benih abalon (A), abalon hasil seleksi umur 12 bulan (B), dan abalon hasil seleksi umur 8 bulan (C)

Figure 2. Variability morphology of fry abalone (A), and abalone selected rearing in 12 month (B), and abalone selected rearing in 12 month $(C)$

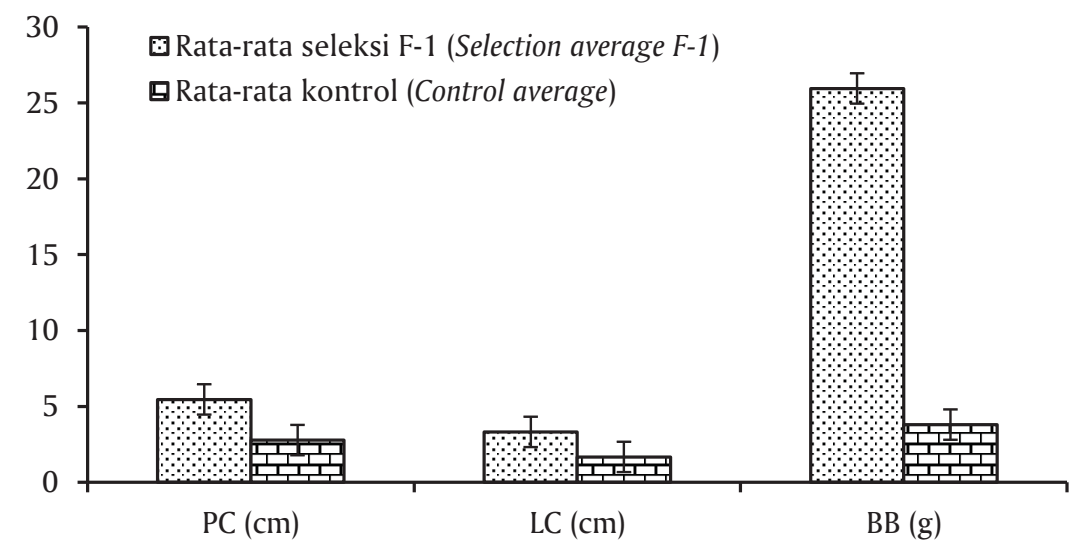

Keterangan (Description): Pc: panjang cangkang (shell length), Lc: lebar cangkang (shell width), Bb: bobot badan (total weight)

Gambar 3. Kemajuan genetik F-1 hasil seleksi abalon (H. squamata) Figure 3. Genetic gain of selected fillial 1 (F-1) of abalone (H. squamata) 
didapatkan $10 \%$. Respons seleksi dapat ditingkatkan dengan meningkatkan nilai S (diferensiasi seleksi), meningkatkan nilai h2 (heritabilitas).

\section{Komposisi Genetik Hasil Seleksi}

\section{Allozyme}

Benih atau calon induk hasil seleksi dianalisis komposisi genetiknya dengan pendekatan allozyme dan mtDNA. Dari hasil penelitian diketahui bahwa reduksi variasi genetik benih hasil seleksi adalah 21,7\%. Ringkasan variasi genetik selengkapnya terlihat pada Tabel 2 .

Pada Tabel 2 terlihat bahwa variasi genetik (jumlah polimorfik loci, jumlah alel per lokus, dan heterozigositas) abalon F-1 terjadi penurunan bila dibandingkan dengan F-0 dari alam. F0 mempunyai variasi genetik lebih tinggi karena jumlah induk tidak terbatas, sehingga terjadi aliran gen (gen flow) dari populasi yang besar. Hal ini jelas terlihat pada jumlah lokus polimorfik pada abalon alam yaitu empat lokus sedangkan pada ikan anakan hatcheri tiga lokus, terjadi penurunan sekitar 25\%. Reduksi heterozigositas teramati (observed heterozygosity) sekitar 21,7\% (0,023 menjadi 0,018 ). Hal ini dapat disebabkan karena adanya efek leher botol sebagai akibat dari penggunaan jumlah induk yang terlalu sedikit, dan jumlah induk yang memijah, dan jumlah induk yang memijah berbeda dalam satu populasi. Terjadinya penyimpangan genetik (genetic drift) pada stok hatcheri terjadi akibat menurunya proporsi heterozigositas dan naiknya proporsi homozigot (Stansfield, 1991). Tave (1993) menyatakan bahwa untuk menekan terjadinya penyimpangan genetik perlu meningkatkan jumlah populasi induk (breeding effective). Konsekuensi dari proses seleksi adalah menurunnya variasi genetik yang dibuat melalui desain penelitian. Beberapa peneliti mengemukakan tentang pentingnya variasi genetik yang harus dipertahankan dalam pembenihan di hatcheri (Sugama \& Prijono, 1998; Taniguchi \& Sugama, 1990).

\section{Hubungan Heterozigositas dengan Pertumbuhan}

Hasil pengukuran sifat-sifat fenotipe yang dihubungkan dengan hasil studi variasi genetik menggunakan penanda isoenzim pada populasipopulasi yang diuji. Dari hasil penelititian terlihat adanya kecenderungan bahwa faktor genetik memberikan pengaruh terhadap pertumbuhan (Gambar 4).

\section{Mt-DNA}

Secara fisik mtDNA terpisah dari DNA lainnnya, sehingga lebih mudah untuk mengisolasi 16.000-20000 bp dari mitokondria dibandingkan dengan miliaran nukleotida dari genom (Park \& Moran, 1995). Kemampuan kecepatan evolusi sekitar 5-10 kali daripada DNA inti merupakan alasan dasar penggunaan mt-DNA ini sebagai marker. Amplifikasi DNA mitokondria (mtDNA) dengan PCR pada abalon $H$. squamata mempunyai panjang pita 600 pasang basa (Gambar 5).

\section{Variabel Situs Haplotipe mt-DNA}

Dari hasil analisis terdadap produk PCR mt-DNA yang disekuen diketahui sebanyak tiga tempat polimorfik yang ditemukan pada abalon hasil seleksi dan kontrol. Haplotipe merupakan variasi genetik antar individu dalam satu spesies yang dianalisis berdasarkan urutan nukleotidanya (Elaman, 2009). Polimorfisme sekuen mtDNA abalon seleksi dan kontrol seperti terlihat pada Tabel 3 .

Haplotipe merupakan urutan nukleotida yang mencerminkan variasi genetik dari setiap individu

Tabel 2. Ringkasan variasi genetik seleksi abalon (H. squamata) hasil seleksi berdasarkan 21 lokus enzim yang terdeteksi

Table 2. Summary of genetic variation of selected abalon (H. squamata) based on 21 loci was detected

\begin{tabular}{lccc}
\hline \multicolumn{1}{c}{ Parameter (Parameters) } & F-0 & F-1 & Reduksi (Reduction) \\
\hline Jumlah sampel yang diamati (No. of samples) & 25 & 25 & - \\
Jumlah loci yang diamati (No. of loci observed) & 21 & 21 & - \\
Jumlah loci polimorfik (No. of polymorphic loci) & 4 & 3 & 25.0 \\
Persentase loci polimorfik (Percentage polymorphic loci) & 0.19 & 0.14 & 26.3 \\
Jumlah alel per lokus (No. of allele per locus) & 1.19 & 1.14 & 4.20 \\
Heterozigositas observed (Ho) & 0.023 & 0.018 & 21.7 \\
Heterozigositas expected (He) & 0.020 & 0.017 & 15.0 \\
Ho/He & 1,150 & 1,058 & \\
\hline
\end{tabular}




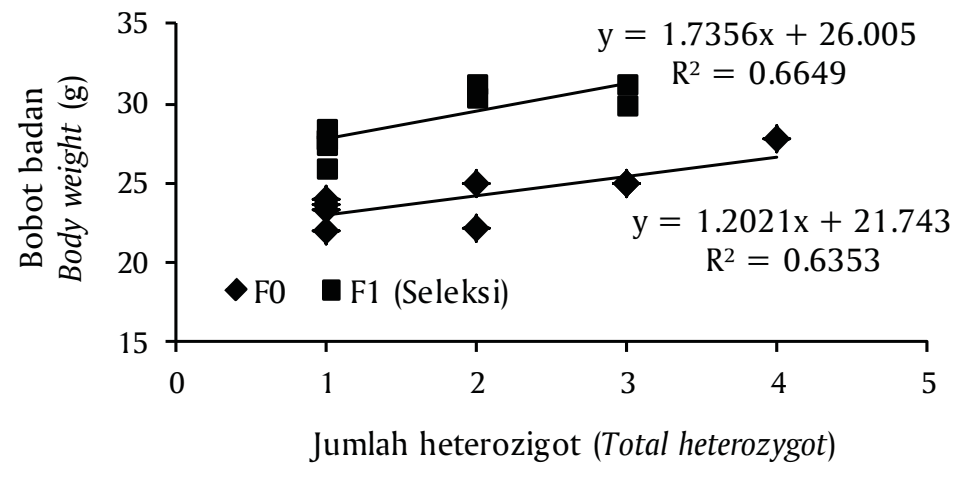

Gambar 4. Hubungan heterozigositas dengan dengan pertumbuhan abalon

Figure 4. Correlation of heterozygosity value with the growth of abalone

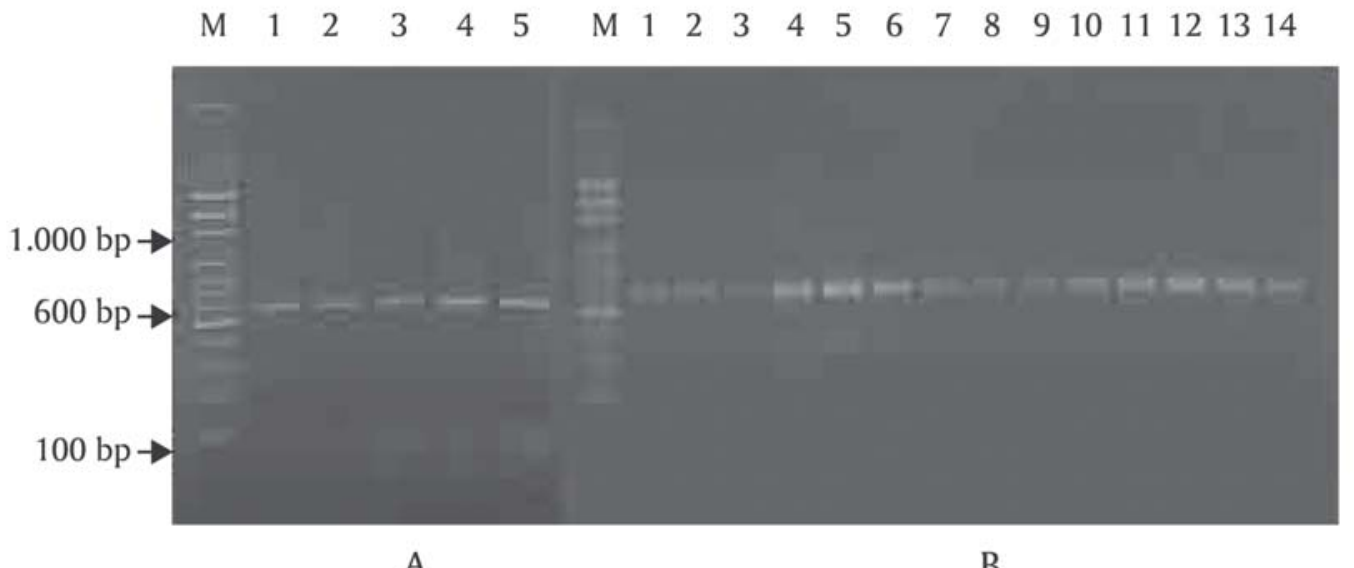

A

B

Gambar 5. Hasil amplifikasi mtDNA abalon, H. squamata pita 1-5 (A); mt-DNA setelah dipurifikasi pita 1-14 dengan panjang pita $600 \mathrm{bp}$ (B); M: marker $100 \mathrm{bp}$

Figure 5. Mt-DNA amplification of $\mathrm{H}$. squamata $(A) ; m t ~ D N A$ after purificationi with fragment size of $600 \mathrm{bp}$ (B); M: $100 \mathrm{bp}$ DNA ladder

Tabel 3. Polimorfisme sekuen mtDNA abalon seleksi dan kontrol Table 3. Polimorphism on mtDNA squence of selected and control

\begin{tabular}{cc}
\hline Haplotipe (Haplotype) & Posisi sekuen (Sequence position) \\
\hline \#678111_B1_Primer_PHO_IV_F & AGCGTAGACC C \\
\#678112_B2_Primer_PHO_IV_F & GGCACGGACC C \\
\#678113_B3_Primer_PHO_IV_F & GGCACGGACC C \\
\#678114_B4_Primer_PHO_IV_F & GGCACGGACC C \\
\#678118_K4_Primer_PHO_IV_F & GGCACGGACC C \\
\#678117_K3_Primer_PHO_IV_F & GGCACGGACC C \\
\#678116_K2_Primer_PHO_IV_F & GGCACGGACC C \\
\#678115_K1_Primer_PHO_IV_F & GGCACGGATA C \\
\hline
\end{tabular}

Keterangan (Description):

B1-B4:Besar (terseleksi) (Big (selected))

K1-K4:Kontrol (Control) 
dalam satu spesies. Haplotipe abalon hasil seleksi \#678111_B1_Primer_PHO_IV_F, mempunyai sekuen yang berbeda dengan abalon hasil seleksi lainnya. Hal yang sama juga terlihat pada \#678115_K1_Primer_PHO_IV_F, adanya perbedaan dengan individu ukuran kecil lainnya. Dua tipe haplotipe tersebut sangat spesifik terlihat pada populasi abalon yang mempunyai pertumbuhan berbeda. Namun demikian hal ini mungkin juga terjadi karena jumlah sampel yang terlalu sedikit atau faktor lingkungan. Faktor lain yang memengaruhi pertumbuhan pada sistem budidaya antara lain suhu, kepadatan (densitas), periode penyinaran, salinitas, oksigen, serta pasokan pakan (Stickney, 2000). Jarak genetik (genetic distance) dari empat belas sekuen haplotipe yang ditemukan antara induk, F-1 seleksi, F-1 kontrol terlihat pada Gambar 6.
Dari Gambar 6 terlihat bahwa kelompok calon induk F-1 besar terseleksi (B1, B2, B3) mempunyai jarak 0,003 dengan (K1, K2, dan K3). Hal ini membuktikan bakwa susunan genotipe F-1 terseleksi berbeda dengan non seleksi (ukuran kecil). Lebih lanjut juga terlihat bahwa induk yang dianalisis bukan merupakan tetua dari anakannya. Hal ini dapat disebabkan karena jumlah sampel yang dianalisis terlalu sedikit sehingga populasi induk yang memijah tidak terwakili untuk dianalisis.

\section{KESIMPULAN}

Pembentukan populasi abalon F-1 dengan seleksi individu lebih baik 22,15 g (17,93\%). Namun demikian konsekuensi dari proses seleksi adalah menurunya variasi genetik yang dibuat atau diharapkan akibat desain penelitian.

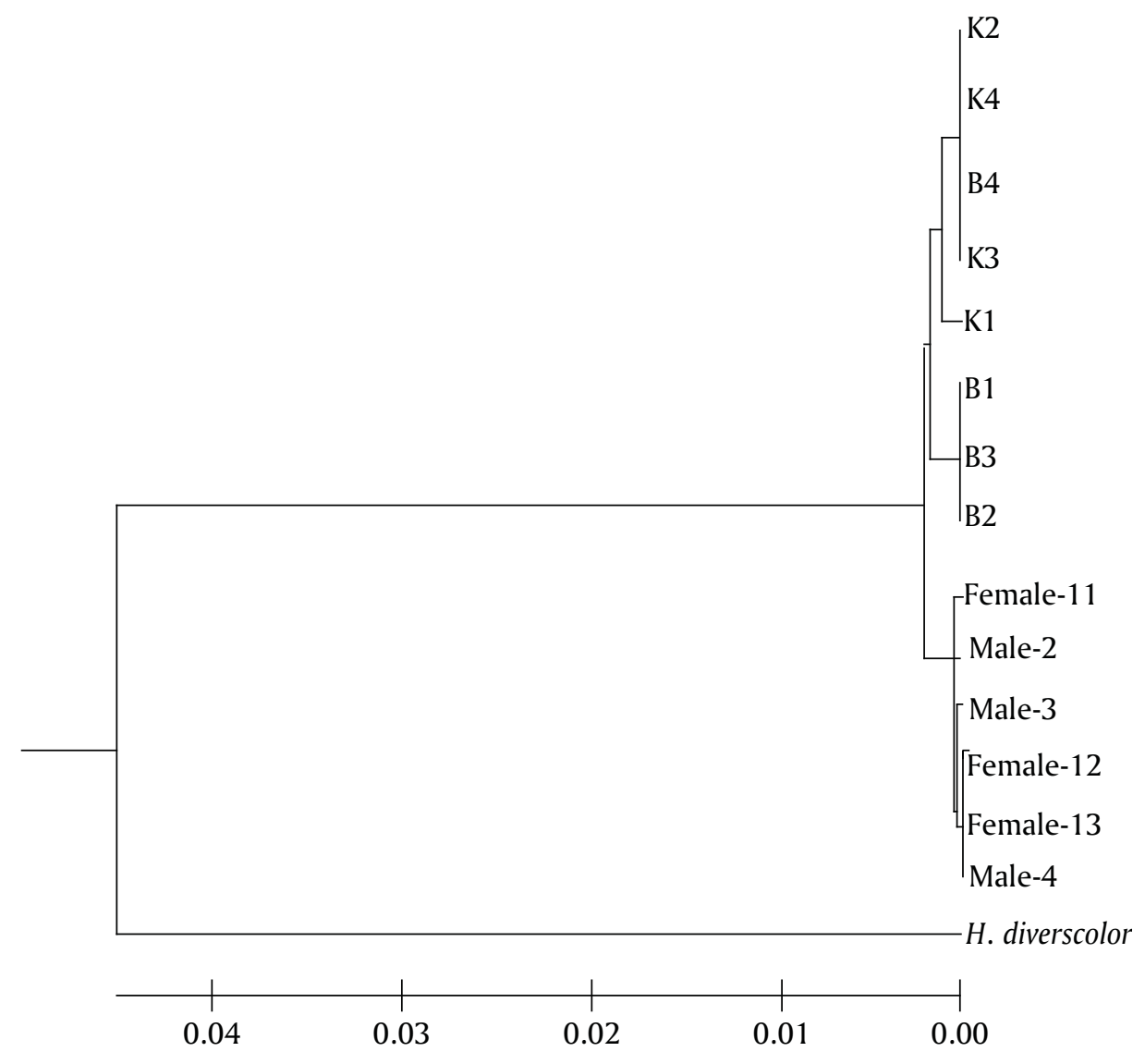

Gambar 6. Dendrogram jarak genetik dari induk, F-1 (terseleksi dan kontrol) komparasi dengan data yang ada di Gene Bank abalon $H$. divesicolor super texta COI kode akses AY 146401

Figure 6. Dendrogram of genetic distance of parent and off springs (selected and control) compared to data Gene Bank abalone H. divesicolor super texta COI acession number AY 146401 


\section{DAFTAR ACUAN}

Allendorf, F.W., \& Utter, F.M. (1979). Population genetics. In Fish Physiology, Vol. III. Hoar, W.S., \& Randall, D.J.J.R. (Eds.).

Carsono, N., Darniadi, S., Ruswandi, D., Puspasari, W., Kusdiana, D., \& Ismail, A. (2004). Evaluasi fenotipik, variabilitas dan heritabilitas karakter agronomi penting pada galur murni jagung S4A. Dalam Astanto Kasno et al. (Eds.). Prosiding Lokakarya PERIPI VII. Dukungan Pemuliaan Terhadap Industri Perbenihan pada Era Pertanian Kompetitif. PERIPI dan Balitkabi. hlm. 312-319.

Elaman, R.I. (2009). Keragaman fenotip dan genotip abalone mata empat (Haliotis squamata) dari lokasi pantai yang berbeda di Bali melalui analisa DNA mitokondria. Tesis. Program Magister Program Studi Bioteknologi Pertanian, Universitas Udayana. Denpasar, $68 \mathrm{hlm}$.

Gustiano, R., Otong, Z.A., \& Nugroho, E. (2008). Perbaikan pertumbuhan ikan nila (Oreochromis niloticus) dengan seleksi family. Media Akuakultur, 3(2), 98-105.

Lynch, M., \& Milligan, B. (1994). Analysis of population-genetic structure using RAPD markers. Molecular Ecology, 3, 91-99.

Metz, E.C., Robless-Sikisaka, R., \& Vacquier, V.D. (1998). Nonsynonymous substitution in abalone sperm fertilization gene excedes substitution in introns and mitocondrial DNA. Proc. Natl.Acad. Sci. USA, 95 pp. http:www.pubmedcentral.nih.gov. (diunduh 20 November 2011).

Park, L.K., \& Moran, P. (1995). Development in molecular genetic techniques in fisheries. In: Carvalho, G.R., \& Pitcher, T.J. (Eds.). Molecular Genetics in Fisheries. Chapman \& Hall. London, p. $1-27$.
Permana, I G.N., Moria, S.B., Haryanti, \& Sugama, K. (2003). Genetic identification and variation of red snapper, Lutjanus sp. through allozyme electrophoretic analysis. Indonesian Fisheries Research Journal, 9(1), 33-40.

Ponzoni, W.R., Hamzah, A., Tan, S., \& Kamaruzzaman, K. (2005). Genetic parameters and response to selection for live weight in GIFT strain of nile tilapia (Oreochromis niloticus). Aquaculture, 247, 203210.

Poehlman, J.M. (1979). Breeding field crops. Edisi ke2. Connecticut: The AVI Publishing. Westport. 486 pp.

Rusdi, I., Susanto, B., Rahmawati, R., Ismi, S., Yudha, H.T., \& Septory, R. (2009). Perbaikan kualitas induk dan larva-juvenil abalon (Haliotis squamata) melalui pengelolaan lingkungan. Laporan teknis BBRPBL-Gondol. Bali, $35 \mathrm{hlm}$.

Stickney, R.R. (2000). Abalone culture. Encyclopedia of Aquaculture. California. p 1-6. per (Cromileptes altivelis) Seed Production in Indonesia. Fifth Asian Fisheries Forum Chiang Mai. Thailand, 33 pp.

Sugama, K., \& Prijono, A. (1998). Biochemical diffrentiation among wild population of milkfish, Chanos-chanos. Indonesian Fisheries Research Journal, 4(1), 11-18.

Stansfield, W.D. (1991). Theory and problems of genetics. Second Edition. Mc Graw-Hill Inc. (Alih bahasa: Apandi, M., \& Hardy, L.T.( 1991) Genetika. Penerbit Erlangga. Jakarta.

Taniguchi, N., \& Sugama, K. (1990). Genetic populatian and structure of red sea bream in the coastal waters of Japan and in the East China Sea. Nippon Suisan Gakkaishi, 56, 1069-1077.

Tave, D. (1983). Genetic for fish hatchery managers. Second Edition. An AVI book. Published by Van Nastrand Reinhold. New York, 415 pp. 